\title{
Board Gender Diversity and Performance of Listed Deposit Banks in Nigeria
}

\author{
Aladejebi Olufemi \\ University of Lagos Business School, University of Lagos, Lagos, Nigeria \\ Email address: \\ oaladejebi@ulbs.unilag.edu.ng \\ To cite this article: \\ Aladejebi Olufemi. Board Gender Diversity and Performance of Listed Deposit Banks in Nigeria. European Business \& Management. \\ Vol. 7, No. 1, 2021, pp. 14-23. doi: 10.11648/j.ebm.20210701.13
}

Received: February 12, 2021; Accepted: February 24, 2021; Published: March 4, 2021

\begin{abstract}
Gender diversity is becoming an issue for boards of companies, regulators, and investors worldwide. Nigeria is not an exception. It is assumed that board gender diversity significantly improves corporate governance and financial performance. Recently, women in both senate and House of representative met and agreed to pursue 35\% appointment in public appointments. The women eventually sent a representation to discuss this with President Mohammadu Buhari. This study's main objective is to examine the relationship between gender diversity and quoted deposit money banks' performance in Nigeria using descriptive statistics, trend, and correlation analysis. Data was collected through the websites of 13 publicly quoted banks on the Nigerian stock exchange. Gender of directors was sieved by using the biography section of Annual report, use of gender-specific pronouns 'she,' the third is the usage of address 'Mr' and 'Mrs' while the use of the first name was also used to determine the Gender. Data were analysed by using SPSS. Trend analysis of each bank's percentage of female board members between 2015 and 2019 shows an unstable trend. The rate at which the female Gender occupies the Board in the banks does not appear to have a specific pattern to make inferences. It also lacks a strong relationship between the number of female board members and banks' performance. There is a weak negative relationship between earnings per share and female board members' percentage. It can be concluded that the inclusion of women on the Board of a company does not necessarily translate into an improvement in a company's financial performance.
\end{abstract}

Keywords: Board Diversity, Gender Diversity, Measurement of Corporate Performance, Agency Theory, Stakeholder Theory, Resource Dependency Theory

\section{Introduction}

Generally, all over the world, gender equality among publicly quoted corporations has become on of the main goals of regulators, investors, and boards. However, Nigeria is not an exception as Gender diversity is becoming an issue such that women are agitating for more slots in both public and private organizations. Recently, women in both senate and House of representative met and agreed to pursue 35\% appointment in public appointments. The women eventually sent a representation to discuss this to President Mohammadu Buhari. In an analysis done by Delloite Nigeria, in 2018, women have $17.4 \%$ as board members of a sample of 138 companies and $5.8 \%$ as chairpersons. Gender Diversity is essential when discussing board composition. Pfeffer [57], introduced the concept of organizational demography. He asserted that demographic composition is a better predictor of outcomes in an organization. According to Pfeffer [57], organizational demography is "the composition, in terms of basic attributes such as sex, age, educational level, race, length of service, residence, of the social unit understudy." The call for more women on the Board of companies is increasing [17].

Regulators and academics have emphasized board diversification due to the collapse of some giant companies and corporate scandals [66]. Developed countries such as UK, USA, and European countries research Gender diversity. National Gender policy was established in Nigeria in 2006. The framework for the strategic implementation policy in 2008 , this policy call for at least $35 \%$ female representation in politics in both appointment and election position [25]. The First woman to chair the Board of a bank was Bola Kuforiji Olubi, United Bank for Africa (UBA), in 1984. At the same time, Mrs. Ibukun Awosika was appointed First Bank's chairperson on September 7, 2015. Mrs. Mosumola 
Bello-Olusoga was also appointed the chairperson of Access Bank in 2015, and Mrs. Osaretin Demuren was appointed the chairperson of GT Bank plc also in 2015 [33]. Recently, Fidelity Bank PLC and FCMB PLC appointed Mrs. Nneka Onyeali - Ikpe and Mrs. Yemisi Edun as their Managing Director and acting Managing Director. There are a plethora of over 30 studies carried out by academics, women's groups, consulting firms accounting management consulting firms, and investment firms from different countries, all revealing a positive relationship between more women in senior corporate leadership roles and a firm's better financial performance [49]. There has been an increase in research on diversity in the composition of board members $[75,71,30,1]$

\section{Problem Statement}

According to research conducted by Şener, \& Karaye, in 2014 [66], The inclusion of women among Board members of a company have been noticed to have a good consequence on a company's financial performance. Women have better attendance record of board meetings compared to men thereby increasing the assurance of all parties to a company [43]. The call for more women on the Board of companies is increasing [17]. The representation of women on boards of Directors is a significant issue because it increases the source of qualified human resources' thus, contributing to increased competitiveness among firms $[24,12]$. The gender-diversity of the Board influences the quality of financial reporting. This could largely be attributable to female executives' sociopsychological characteristics who obviously reflect in their aversion to fraud, risk, and earnings manipulation [17].

Existing empirical literature on the relationship between gender diversity and firm performance are inconclusive. For example, $[28,11]$ found in their studies a positive link between gender diversity and firm performance; Daunfeldt \& Rudholm [19], Adams \&Ferreira [2, 9], and Rose [64] found that gender diversity does not significantly contribute to firm performance. Mohammad, Abdullatif \& Zakzouk [48] carried out a study exploring whether the percentage of women on boards of directors and medium-level executive management positions in Jordanian banks affected these banks' financial performance, using a multiple regression using 2009 to 2016 data. The findings revealed no statistically significant relationship between percentages of women on boards and the banks' financial performance. Research on gender diversity and performance relationships is inconclusive [28]. In a study conducted by Akpan \& Amran [4], part of the conclusion among 90 sampled firms from the quoted Nigerian stock exchange firms from 2010 to 2012 showed a negative significance between board women and turnover. Women's appointment is window dressing as the percentage is too small for a meaningful positive effect on company performance.

\section{Objective of the Study}

This study's main objective is to examine the relationship between gender diversity and performance in Nigeria using descriptive statistics, trend, and correlation analysis.

\section{Literature Review}

\subsection{Theoretical Framework}

\subsubsection{Agency Theory}

One of the oldest theories is Agency theory, the literature of management economics [74, 16]. Agency theory describes how a firm will set about to ensure that stakeholder interests are protected in view or difference in ownership and management functions [35]. Agency theory can be linked to Smith's groundbreaking work [67]. The wealth of Nations, where he asserted that 'a manager with no direct ownership of a company, would not make the same decisions or exercise the same care as an owner of that company'. This view was popularized by Berle \& Means [8] and Jensen \& Mecking [35] as the agency theory. Agency theory examines the problems that arise in a firm due to the separation of owners and management and how they can be minimized [54].

Agency theory has been described as a significant theory of the firm and corporate governance in academic circles [38, $10,39]$. The core of agency theory is the principal-agent relationship where one person (the principal) engages another (The Agent) to perform a service on their behalf involving decision-making authority [68]. The theory is centered on many company's managers who are not owners but agents of owners engaged in managing the company on their behalf [73]. A problem in Agency may arise whenever managers have incentives to pursue their interest at the expense of shareholders [73].

Perrow [55] criticized agency researchers who concentrated on the agent side of the principal and agent problem' that problem may also arise from the principals who want to deceiver, shirk, and exploit the agents. Agents are unknowingly dragged into work with the hazardous working environment and without any scope for encroachment, where principals act as an opportunist [55]. The theory assumes that contracting can eliminate the agency problem, but practically it faces many hindrances like rationality, fraud, information asymmetry, and transaction cost. [54].

\subsubsection{Stakeholder Theory}

Frreman (27) explained that a stakeholder is any person or persons that can influence or is influenced by the goals and objectives of any firm. Groups such as employees, suppliers, environmental groups, competitors, government, local communities are some of the groups that are vital in stakeholders theory [44]. Stakeholder theory centers around all stakeholders contributing and benefitting from its activities [37].

According to Alqatan, Chbib \& Hussainey [5], stakeholder theory is used to create a scenario that measures the company's performance when a company's directors direct their energies at rewarding all stakeholders instead of directing their energies solely towards rewarding the shareholders. The stakeholder theory considers organizations 
a collection of groups whose objectives must be coordinated by managers [27]. Stakeholders theory is criticized for being too broad, thereby creating an avenue for confusion and inefficiency in decision making [68].

\subsubsection{Resource Dependency Theory}

Resource dependency theory is based on Pfeffer \& Salancik's [58] postulations. According to the authors, "when an organization appoints an individual to a board, it expects the individual will come and support the organization, will concern himself with its problems, will invariably present it to others and will try to aid the organization. Nicholson and Kiel [50] asserts that a board's provision of resources is directly related to firm performance. Resources help diminish the firmand assist in the firm's survival [59]. Resource dependency theorists believe that having board members with different cultural background skills, Gender will enhance a firm's performance [73]. Resource dependency theory was initially started to give another view to economic theories of board interlocks and mergers and precisely understand the type of inter organizations relations that have played such a serious role in recent "market failures" [57]. Resource dependency theory provides a theoretical foundation for the Board of directors' role as a resource to the firm [36]. The appointment of new board members helps gain access to resources critical to firm success [36].

\subsection{Functions of Board of Directors}

One of the company's Board of Directors' primary responsibility is to "oversee the actions and decisions" of management [65]. Boards of Directors are the most influential decision-making unit of a corporation [42]. The Board of directors is the strategic decision-making body of an organization. They also ensure that an organization performs at the optimal level. The Board of directors ensures that the vision, mission policies, and strategic decisions are well implemented in an organization [66].

Section 305 (1) of CAMA states that Part of Section 305 of CAMA states that the duties of a director is fiduciary and must be done with serious integrity on any transaction carried out on a firm's behalf. A director is expected to safeguard the assets of a firm, act in the best interest of a firm, consider the environment a firm is carrying out its business and act skillfully.

\subsection{Board Gender Diversity and Advantages}

Board diversity can be referred to as a structural phenomenon consisting of Gender, age, and ethnicity, while others refer to board diversity as a structural phenomenon comprising board independence, CEO duality, and director ownership [32]. The Board's composition could be according to Gender, nationality, age of the directors, or ethnicity [51]. Board diversity can be defined as variety amongst the Board of directors about characteristics such as kinds of expertise, personality, age, managerial background, learning style, Gender, values, and education [69]. Eulerich, Velte \& Uum
[22] asserted that board diversity represents major corporate governance (CG) mechanism. One way of enhancing corporate governance is board diversity [42]. According to Anazonwu, Egbunike, \& Gunardi [6], there is a positive correlation between board diversity and sustainability reporting and performance $[61,47,60]$.

According to Robbins \& Decenzo [62], Board gender diversity depicts the varied personal characteristics that make the workforce heterogeneous. According to Imade [34], board gender diversity is part of board diversity. It refers to the difference in the number of women on the Board of corporate firms. Reducing the gender divide is a matter of fairness and effective governance, and inclusive economic growth [21]. Central Banks of Nigeria (CBN) regulations direct a minimum of 30 percent female representation on the boards of Nigerian commercial (deposit) banks [33].

According to WIMBIZ [78], there are many arguments in favour of gender diversity of the Board: redress of injustice, better decision making, improved corporate performance and innovations, maximum utilization of pool of talent, and mirror of the market as women make about $80.5 \%$ of consumer decisions. Gender diversity and the addition of more women in top executive management positions and boards of directors can add value to organizations [70]. Gender diversity can lead to more social sensitivity. When solving problems [76] and increased diversity in thought and result in better company performance [23]. Groysberg \& Bell [29], found from a survey that $90 \%$ of female directors and $56 \%$ of male directors said that women add fresh perspectives and thought diversity to boards of directors. Women are more collaborative and trustworthy than men, improving board dynamics [14]. According to Mckinsey and comapny [46], companies that include women in their executive teams are $25 \%$ likely to have above average profitability. At least $20 \%$ of board members of Nigeria's top companies are female, above the world average of $17 \%$ for female representation on boards [52]. Three of the top 20 most capitalized firms in Nigeria have women as the Board's chair [52]. Countries such as Botswana and Kenya are better than Nigeria in women occupying board positions. The Nigerian Code of Corporate Governance 2018, which is pertinent to private and public companies, shows the importance of diversity on boards and committees. The gender diversity requirement included in the Nigerian Code is not absolute but is subject to competence, independence, and integrity considerations [20].

\subsection{Hindrances to Women Board Membership}

The under-representation of women within boards is known as the "glass ceiling problem" [7]. The fundamental causes for the little representation of women on board directorships have been the focus of significant research when considered in European, North American, and Asian economies markets. Not many studies exist in Africa that examine this reality even if the socio-economic situation increasingly requires it [53]. Some of the challenges that restrict women from getting board appointment according to [78] includes persuasion of women 
to make perceived "feminine" carrier choices that offer to preparation for executive positions, gender self-schema, discriminatory nurturing of girls and boys; society's expectations and cultural prejudices about the role of men and women, stereotype leadership styles and positions, with a preference for "male" leadership styles limited pool of senior women executives to feel the board pipeline, women often do not belong to the informal inner circles of men who are the power brokers, tendency to form new boards that resemble the previous Board in order to maintain board comfort and 'perceived' cohesion; other challenges include a choice of career, lack of ambition, women employment issues and family obligations, women's reluctance to promote other women and high reputation risks [78]. Placing men as the leader of the society limits female participation in top leadership positions [66].

According to IFC [33], the following recommendations will enhance female Board Directorship in quoted companies: formal and documented policies on Board appointment, term limits, integrating Gender diversity into the successionplanning process, recruiting beyond traditional networks, internal goal setting, corporate culture, career-progression programs, formal mentorship program mandatory quotas by regulators, e.g., $\mathrm{CBN}$, comply or explain policy by regulators, e.g., securities and exchange commission (SEC), work/life balance (aspiring women to Board membership should have a support system), professional and personal development, advocacy through male champions, shareholding (ownership) can help attain directorship. Board diversity is critical for sustainability [33].

\section{Empirical Review}

Imade [34] researched board gender diversity among 72 quoted companies on the Nigerian stock exchange between 2006 and 2016; the results revealed that board gender diversity has a significant effect on corporate performance (Return on Asset) quoted companies Nigerian stock exchange. Temile, Jatmik \&Hidayat [72], examined the impact of gender diversity, earnings management practices and quoted companies' corporate performance in Nigerian. The researchers used secondary data from the annual financial reports of the selected 50 firms over a period of 5 years (2010-2014). The study showed a negative but insignificant relationship between female memberships on audit committees and female chief executive officers and their financial performance in Nigeria. Meanwhile, proportion of females on the Board, female chief financial officer, and leverage had a positive impact on the firms' corporate performance in Nigeria.

In an overt by Ogboi \& Enilolobo [51], to investigate the effect of board diversity on bank performance for the period: 2011-2015 using the fixed effect Generalized Least Square Regression, the result showed that gender diversity and board composition was positively linked to financial performance.

In a study by Garba \& Abubakar [28] among 12 quoted insurance firms using ROE, ROA, and TOBIN's $Q$ as measures of firm performance for 6years (2004 to 2009) and applying Feasible Generalized Least Squares (FGLS) and random effects estimators, the findings showed that gender diversity has a positive influence on insurance companies performance.

Kwanbo \& Abdul-Qadir [41] carried out research on the effect of the Board's composition on banks' performance adjudged healthy by the central bank of Nigeria. The study revealed that; board composition does not significantly relate to and impact the return on capital employed of banks in Nigeria.

Chandrasekharan [13] researched the influence of board diversity on quoted deposit money banks' financial performance in Nigeria using fixed effect regression model. The outcome shows that board diversity has a major impact on the quoted deposit banks' financial performance.

Ujunwa (74) performed a research on Firm corporate diversity on 122 quoted Nigerian companies adopting panel data method. The data was from 1991 to 2008. The areas tested in the research are board ethnicity, nationality and gender. While gender diversity was negative both Board nationality and ethnicity were positive The position of Curtis, Schmid \& Struber [15] was shared by Willows \& Van Der Linde $[77,26,40]$ that women representation on the board of companies were associated with good financial performance. In a research conducted by McKinsey and company [46] on 1007 firms from America, Australia, Asia, Afica, Europe and South America, it was discovered that $25 \%$ of firms with gender diversity among management cadre performed better than their counterparts by $21 \%$ on profit level and in terms of creation of value on long term basis by $27 \%$.

Peterson Institute for International Economics [56], conducted research titled "Is gender diversity profitable" Evidence from a global survey among 21, 980 firms headquartered in 91 countries. Part of the conclusion was that for profitable firms, a move from no female leaders to $30 \%$ female representation is associated with a $15 \%$ increase in the net revenue.

\section{Methodology}

Data was collected through the websites of publicly quoted banks on the Nigerian Stock Exchange. In accordance with Dang, Bender, and Scotto [18], Ahern and Dittmar [3], and Hillman, Cannella, and Harris [31], directors' gender identification was organized and completed based on biography, address, gender specific pronouns, and the use of first names. SPSS was used to analyse the data, while the ratio of female directors to board size was used to calculate the gender diversity.

\section{Results}

The board compositions' descriptive statistics are summarized in Tables (Female Director in Banking Sector and Performance by Bank Using Earning Per Share (EPS)) 
and figures (Trend Analysis, Trend Analysis: Average and below. Average Percentage of Female Board Members Per Bank.)

Table 1. Female Director in Banking Sector.

\begin{tabular}{|c|c|c|c|c|c|c|c|c|c|c|c|}
\hline \multirow{2}{*}{$\mathbf{S} / \mathbf{N}$} & \multirow{2}{*}{ Name } & 2015 & $\%$ & 2016 & $\%$ & 2017 & $\%$ & 2018 & $\%$ & 2019 & $\%$ \\
\hline & & TBDF & Women & TBDF & Women & TBDF & Women & TBDF & Women & TBDF & Women \\
\hline 1 & Access Bank PLC & $4 / 16$ & 25 & $5 / 16$ & 31 & $6 / 17$ & 35 & $5 / 15$ & 33 & $6 / 16$ & 38 \\
\hline 2 & Ecobank Nigeria PLC & $4 / 13$ & 31 & $5 / 12$ & 42 & $3 / 11$ & 27 & $4 / 11$ & 36 & $4 / 13$ & 27 \\
\hline 3 & Fidelity Bank PLC & $4 / 15$ & 27 & $3 / 18$ & 20 & $4 / 13$ & 20 & $3 / 15$ & 20 & $3 / 16$ & 19 \\
\hline 4 & First bank Nigeria Limited & $3 / 19$ & 16 & $3 / 11$ & 27 & $3 / 10$ & 30 & $3 / 10$ & 30 & $4 / 13$ & 23 \\
\hline 5 & First city Monument Bank & $0 / 10$ & 0 & $0 / 10$ & 0 & $1 / 12$ & 8 & $1 / 11$ & 9 & $4 / 11$ & 36 \\
\hline 6 & Guaranty Trust Bank PLC & $3 / 14$ & 21 & $4 / 14$ & 29 & $5 / 15$ & 33 & $4 / 16$ & 25 & $4 / 14$ & 29 \\
\hline 8 & Sterling Bank PLC & $5 / 16$ & 31 & $4 / 14$ & 29 & $4 / 15$ & 27 & $4 / 17$ & 24 & $3 / 15$ & 21 \\
\hline 9 & Union Bank of Nigeria PLC & $4 / 17$ & 24 & $4 / 16$ & 25 & $4 / 15$ & 27 & $3 / 15$ & 20 & $4 / 17$ & 24 \\
\hline 10 & United Bank for Africa PLC & $4 / 16$ & 25 & $3 / 19$ & 16 & $1 / 9$ & 11 & $4 / 19$ & 21 & $3 / 20$ & 15 \\
\hline 11 & Unity Bank PLC & $5 / 15$ & 33 & $5 / 16$ & 31 & $4 / 9$ & 44 & $3 / 9$ & 33 & $3 / 9$ & 33 \\
\hline 12 & Wema Bank PLC & $4 / 14$ & 29 & $4 / 12$ & 33 & $4 / 13$ & 31 & $4 / 12$ & 33 & $4 / 11$ & 36 \\
\hline 13 & Zenith Bank PLC & $2 / 12$ & 17 & $1 / 13$ & 8 & $1 / 14$ & 7 & $1 / 13$ & 8 & $0 / 14$ & 0 \\
\hline & Average $\%$ per year of total deposit bank & & 12 & & 10 & & 10 & & 10 & & 10 \\
\hline
\end{tabular}

Table 1. Continued.

\begin{tabular}{|c|c|c|c|c|c|c|c|}
\hline \multirow{2}{*}{$\mathbf{S} / \mathbf{N}$} & \multirow{2}{*}{ Name } & AV & 2019 & 2019 & 2019 & 2019 & 2019 \\
\hline & & $\%$ & $\mathbf{C P}$ & ED & MD & NED & TF \\
\hline 1 & Access Bank PLC & 32.48 & 1 & 3 & 0 & 2 & 6 \\
\hline 2 & Ecobank Nigeria PLC & 32.67 & 0 & 1 & 0 & 3 & 4 \\
\hline 3 & Fidelity Bank PLC & 21.08 & 0 & 3 & 0 & 0 & 3 \\
\hline 4 & First bank Nigeria Limited & 25.23 & 1 & 0 & 0 & 3 & 4 \\
\hline 5 & First city Monument Bank & 10.76 & 0 & 2 & 0 & 2 & 4 \\
\hline 6 & Guaranty Trust Bank PLC & 27.38 & 1 & 1 & & 2 & 4 \\
\hline 8 & Sterling Bank PLC & 26.29 & 0 & 1 & 0 & 2 & 3 \\
\hline 9 & Union Bank of Nigeria PLC & 23.75 & 1 & 1 & 0 & 2 & 4 \\
\hline 10 & United Bank for Africa PLC & 17.59 & 0 & 0 & 0 & 3 & 3 \\
\hline 11 & Unity Bank PLC & 35.14 & 0 & 0 & 1 & 2 & 3 \\
\hline 12 & Wema Bank PLC & 32.47 & 0 & 1 & 0 & 3 & 4 \\
\hline 13 & Zenith Bank PLC & 7.84 & 0 & 0 & 0 & 0 & 0 \\
\hline
\end{tabular}

Tbdf $=$ Total of board of director/number of female Director

$\mathrm{AV}=$ Average

$\mathrm{CP}=$ Chairperson

ED: Executive Director

$\mathrm{MD}=$ Managing Director

NED $=$ Non-executive Director

$\mathrm{TF}=$ Total Female

Source: Field research analysis

Table 2. Performance by Bank Using Earning Per Share (EPS).

\begin{tabular}{|c|c|c|c|c|c|c|c|c|}
\hline & \multirow{2}{*}{$\begin{array}{l}\text { AVERAGE \% PER YEAR OF TOTAL } \\
\text { DEPOSIT BANK }\end{array}$} & \multirow{2}{*}{12} & \multirow{2}{*}{10} & \multirow{2}{*}{$\begin{array}{l}10 \\
\text { KOBO }\end{array}$} & \multirow{2}{*}{$\begin{array}{l}10 \\
\text { KOBO }\end{array}$} & \multicolumn{3}{|l|}{10} \\
\hline & & & & & & КОВO & AVERAGE & POSITION \\
\hline $\mathrm{S} / \mathrm{N}$ & NAME & 2015 & 2016 & 2017 & 2018 & 2019 & & \\
\hline 1 & ACCESS BANK PLC & 262 & 245 & 214 & 325 & 284 & 266 & $3 \mathrm{RD}$ \\
\hline 2 & ECOBANK NIGERIA PLC & 56 & 29 & 100 & -8 & 5 & 36.4 & 9TH \\
\hline 3 & FIDELITY BANK PLC & 48 & 19 & 31 & 79 & 98 & 55 & $8 \mathrm{TH}$ \\
\hline 4 & FIRST BANK NIGERIA LIMITED & 6 & 21 & 26 & 26 & 39 & 23.6 & $11 \mathrm{TH}$ \\
\hline 5 & FIRST CITY MONUMENT BANK & 56 & 276.00 & 149 & 234 & 327 & 208.4 & $4 \mathrm{TH}$ \\
\hline 7 & STANBIC IBTC BANK LTD. & 99 & 6 & 250 & 151 & 321 & 165.4 & $5 \mathrm{HT}$ \\
\hline 8 & STERLING BANK PLC & 36 & 18 & 28 & 33 & 35 & 30 & $10 \mathrm{TH}$ \\
\hline 9 & UNION BANK OF NIGERIA PLC & 106 & 94 & 66 & 63 & 84 & 82.6 & $7 \mathrm{TH}$ \\
\hline 10 & UNITED BANK FOR AFRICA PLC & 136 & 131 & 120 & 120 & 183 & 138 & $6 \mathrm{TH}$ \\
\hline 11 & UNITY BANK PLC & 12.34 & 19 & -127.62 & -65.83 & 28.94 & -26.698 & $13 \mathrm{TH}$ \\
\hline 12 & WEMA BANK PLC & 5.9 & 6.7 & 6 & 8.6 & 13.5 & 8.14 & $12 \mathrm{TH}$ \\
\hline 13 & ZENITH BANK PLC & 315 & 362 & 487 & 527 & 574 & 453 & $2 \mathrm{ND}$ \\
\hline
\end{tabular}

Source: Field Research analysis 
Board Gender Diversity and Performance of Listed Deposit Banks in Nigeria

This study aims to study board gender diversity in Nigeria's deposit banks and its relationship with financial performance. Data on the gender ratio and earnings of 13 banks from 2015 to the year 2019 were collected to achieve this.

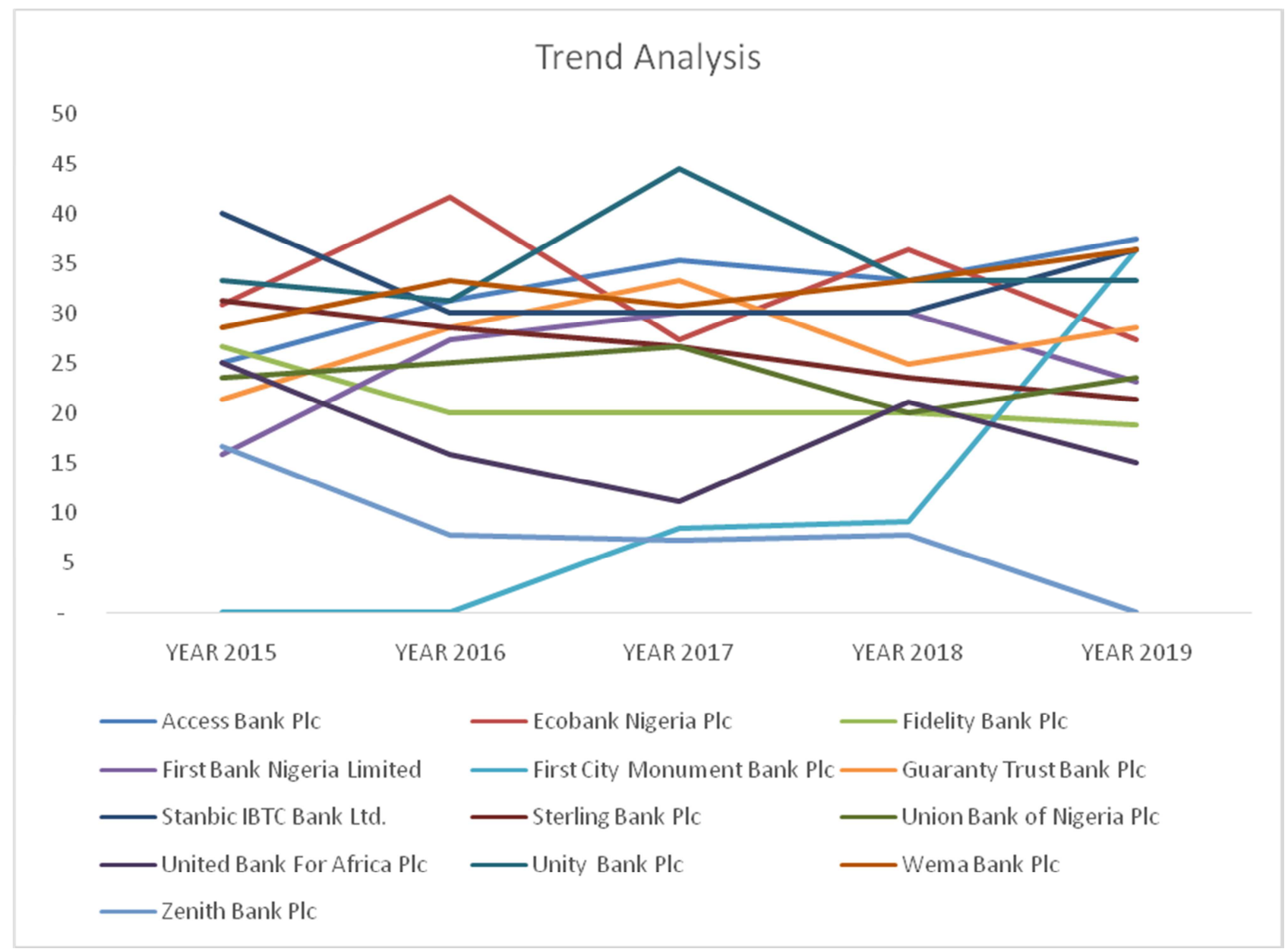

Figure 1. Trend Analysis.

Trend analysis of the percentage of female board members of each bank over the years shows an erratic trend. The rate at which the female Gender occupies the Board in the banks does not appear to have a specific pattern to make inferences.

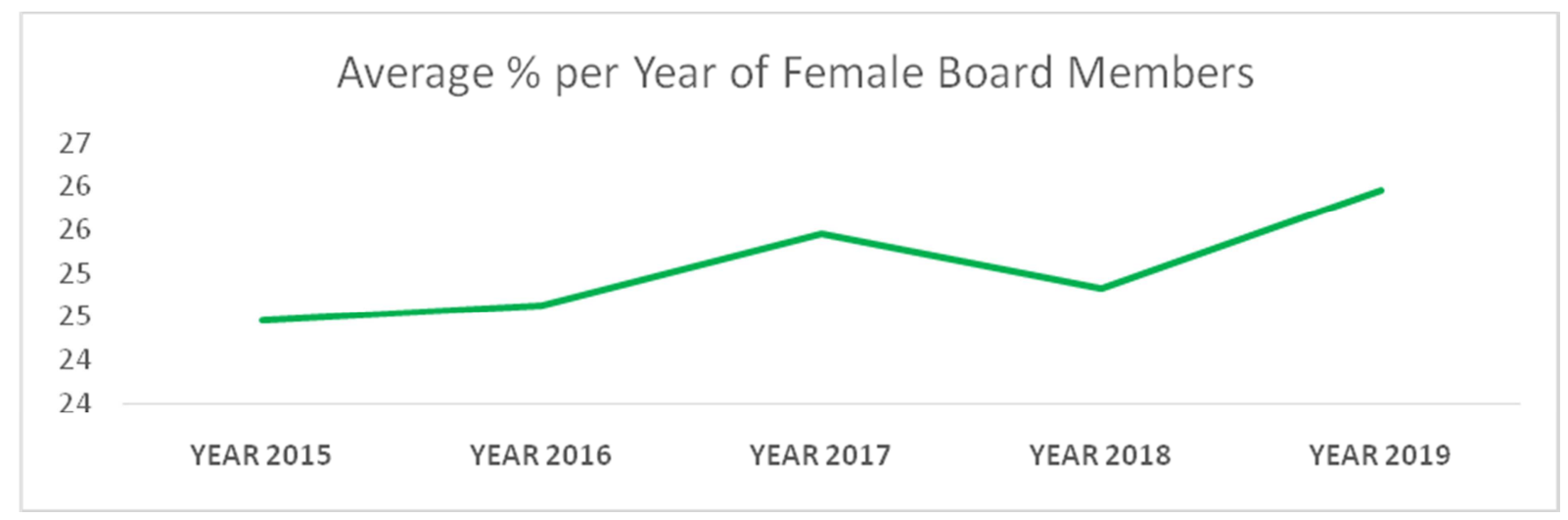

Figure 2. Trend Analysis: Average.

A trend analysis based on all 13 banks' average figures was carried out to ascertain a general view. The analysis showed that the percentage of female board members compared to their male counterparts was lowest in 2015, increased between 2016 and 2017, then dipped in 2018, after which we saw an increase in 2019. 


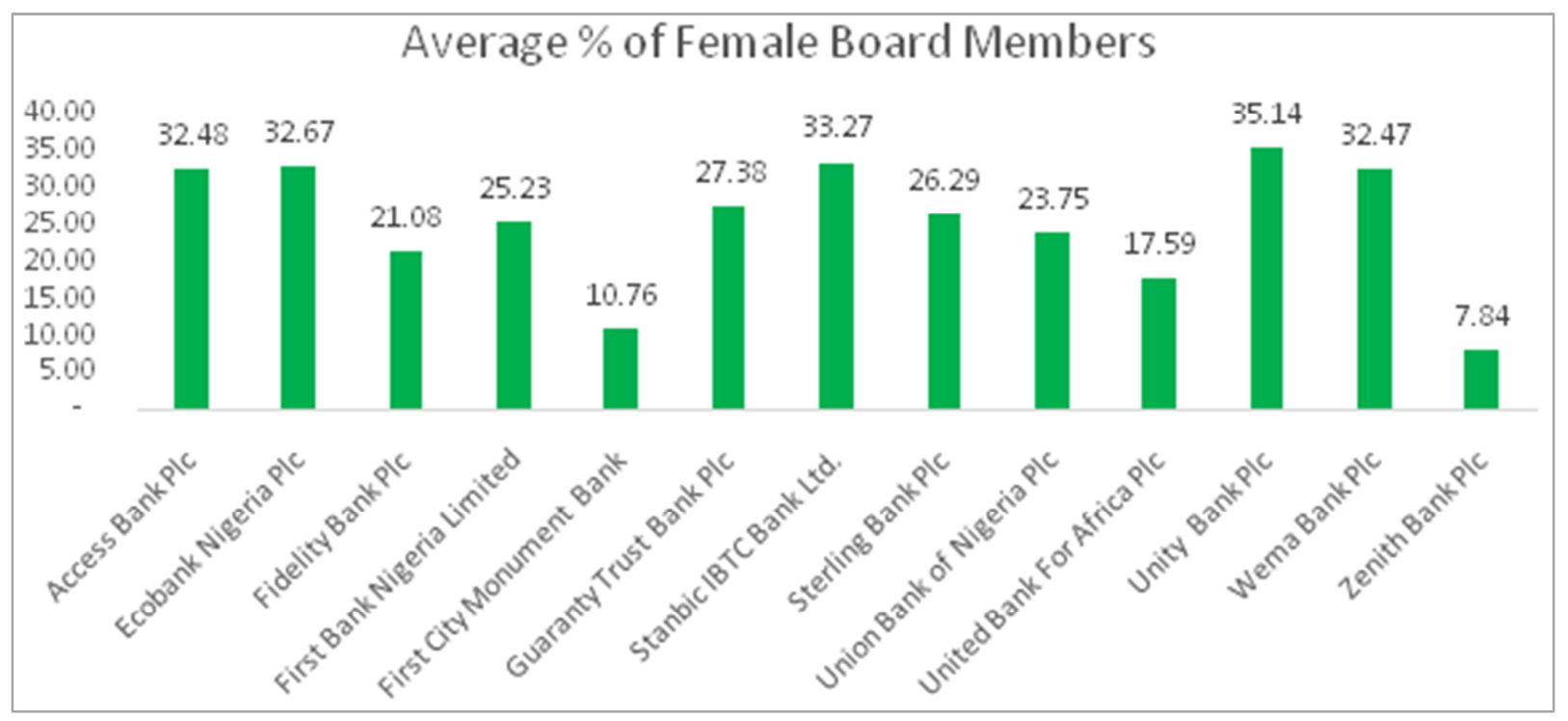

Figure 3. Average Percentage of Female Board Members Per Bank.

The above bar chart shows the distribution of the average percentage of female board members between the years 2015 and 2019 across the banks. Unity bank has the highest, followed by Stanbic IBTC Bank and Ecobank Nigeria.

Correlation analysis between the average earnings per share of banks from 2015 to 2019 and the average percentage of female board members was carried out to determine a relationship's presence. The analysis gave a Pearson Correlation coefficient of -0.43 showing a weak negative relationship between earnings per share and female board members' percentage.

\section{Discussion}

The analysis results show a lack of a specific trend in the percentage of female board members in Nigerian banks between 2015 and 2019. It also lacks a strong relationship between the number of female board members and banks' performance. The study corroborates this position carried out by Kwanbo\&Abdul-Qadir [41] on the impact of board composition on banks' performance considered healthy by the central bank of Nigeria. The study revealed that; board composition does not significantly relate to and impact the return on capital employed of banks in Nigeria. Daunfeldt \& Rudholm [19], Adams \& Ferreira [2], Bøhren \&Strøm [9], and Rose [64] found that gender diversity does not significantly contribute to firm performance.

Mohammad, Abdullatif \& Zakzouk [48] carried out a study exploring whether the percentage of women on boards of directors and medium-level executive management positions in Jordanian banks affected these banks' financial performance, using a multiple regression using 2009 to 2016 data. The findings revealed no statistically significant relationship between percentages of women on boards and the banks' financial performance. On the other hand, Chandrasekharan [13] examined the influence of board diversity on listed deposit money banks' financial performance in Nigeria using fixed effect regression model. The results suggest that board diversity has a significant influence on deposit money banks' financial performance in Nigeria. The total average percentage of female board members based on this study stands as $25 \%$, which shows a low level of gender diversity in Nigerian banks.

\section{Conclusion}

It can be concluded that the inclusion of women on the Board of a company does not necessarily translate into an improvement in a company's financial performance. Other factors need to be considered. Though the average percentage of female board members among Nigeria quoted banks stand at $25 \%$, it can be considered low; it is still higher than the world average of $17 \%$.

For more women to be included on the Board of directors of a company in Nigeria, they need to add value to the management of companies, be more visible, own more shares of companies, make more representation to government, and organized private of $35 \%$ representation of women on Board of directors of companies. Also, an improvement on women's networking, adherence to term limits of directors, adequate succession planning, and improvement in work-life balance. There is also a need for a cultural shift of the belief that women are subordinate to men.

\section{References}

[1] Adams, R. B., Haan, J., Terjesen, S., \& Van, E. H. (2015). Board diversity: Moving thefield forward. Corporate Governance: An International Review, 23 (2), 77-82. doi: 10.1111/corg.12106.

[2] Adams, R., \&Ferreira, D. (2009). Women in the boardroom and their impact on governance and performance. Journal of Financial Economics 94 (2), 291-309. Retrieved from www.econpapers.repec.org. 
[3] Ahern, K. R. \& Dittmar, A. K. (2012). The changing of the boards: The impact on firm valuation of mandated female board representation. Quarterly Journal of Economics, 127, 137-197. doi: 10.2139/ssrn. 1364470 .

[4] Akpan, E. O. \& Amran, N. A. (2014). Board characteristics and company performance: Evidence from Nigeria. Journal of Finance and Accounting, 2 (3), 81-89. doi: 10.11648/j.jfa.20140203.17.

[5] Alqatan, A., Chbib, I. \& Hussainey, K. (2019). How does Board structure impact on firm performance in the UK? Corporate Board: Role, Duties and Composition, 15 (2), 1827. doi: $10.22495 / \mathrm{cbv} 15 \mathrm{i} 2 \mathrm{art} 2$.

[6] Anazonwu, H. O., Egbunike, F. C., \& Gunardi, A. (2018). corporate board diversity and sustainability reporting: a study of selected listed manufacturing firms in Nigeria. Indonesian Journal of Sustainability Accounting and Management, 2, 65-78. doi: 10.28992/ijsam.v2i1.52.

[7] Arfken, D. E., Bellar, S. L. \& Helms, M. M. (2004). The Ultimate Glass Ceiling Revisted: The Presence of Women inCorporate Boards. Journal of Business Ethics, 50 (2), 177 186. doi: 10.1023/B: BUSI.0000022125.95758.98.

[8] Berle, A. A. Jr., and Means, G. C. (1932), The Modern Corporation and Private Property, MacMillan, New York.

[9] Bøhren, O., \& Strøm, R. (2007). Aligned, informed, and decisive: Characteristics of value-creating boards. SSRN Electronic Journal. 1-30. doi: 10.2139/ssrn.966407.

[10] Carney, M., Gedajlovic, E., \& Sur, S. (2011). Corporate governance and stakeholder conflict. Journal of Management \& Governance, 15, 483-507. doi: 10.1007/s10997-010-9135-4.

[11] Carter, D. A., Simkins, B. J. \& Simpson, W. G. (2003). Corporate governance, board diversity, and firm value. Financial Review, 38, 33-53. doi: 10.1111/15406288.00034

[12] Catalyst. (2015). Women in S\&P 500 companies. Retrieved from: www.catalyst.org.

[13] Chandrasekharan, C. V (2012). Determinants of capital structure in the Nigerian listed firms. International Journal of Advanced Research in Management and Social Sciences 1 (2): 108-133. Retrieved from www.garph.co.uk.

[14] Croson, R. \&Buchan. N. R. (1999). Gender and culture: International experimental Evidence from trust games. American Economic Review (February) 89 (2): 386-91. Retrieved from www.repository.upenn.edu.

[15] Curtis, M., Schmid, C. \& Struber, M. (2012). Gender diversity and corporate performance. Credit Suisse AG Research Institute. Retrieved from women.govt.nz.

[16] Daily, C. M., Dalton, D. R., \& Rajagopalan, N. (2003). Governance through ownership: Centuries of practice, decades of research. Academy of Management Journal, 46 (2), 151-158. doi: 10.2307/30040611.

[17] Damagum, Y, M., Oba, V. C., Chima, E. I \& Ibikunle, J. (2014). Women in corporate boards and financial reporting credibility: Evidence from Nigeria. International Journal of Accounting andFinancial Management Research, 4, 1-8. Retrieved from www.tjprc.org.
[18] Dang, R., Bender, A. \&Scotto, M. (2014). Women on French corporate Board of directors: How do they differ from their male counterparts? Journal of Applied Business Research, 30 (2): 490-508. Doi: 10.19030/jabr.v30i2.8420.

[19] Daunfeldt, S. \& Rudholm, N. (2012). Does gender diversity in the boardroom improve firm performance? HUI Working Paper The Swedish Retail Institute, 60. Retrieved from www.ideas.repec.org.

[20] Deloitte Global (2018). Data-driven change Women in the boardroom. A global perspective Sixth edition. Retrieved from global.corpgov.deloitte.com.

[21] Deloitte Global (2017). Deloitte Global finds gender diversity on boards doubled in organizations with female leadership. Press release (June 6) retrieved from www2.deloitte.com.

[22] Eulerich, M., Velte, P. \& Uum, C. U.(2014). The impact of management board diversity on corporate performance - An empirical analysis for the German two-tier system. Problems and Perspectives in Management, 12. 25-39. Retrieved from www.businessperspectives.org.

[23] Ernst \& Young (2009). Groundbreakers: Using the strength of women to rebuild the world economy. retrieved from www.womenable.com.

[24] European Union. (2016). Gender diversity on European boards. Annual report, Brussels. Retrieved from ec.europa.eu.

[25] Fakeye, Y., George, O. J. \&Owoyemi, O. (2012). Women in purgatory: The case of Nigerian women in the boardrooms. Asian Journal of Business and Management Sciences, 1 (10): 134-150. Retrieved from www.ajbms.org.

[26] Francouer, C., Labelle, R. \& Sinclair-Desgange, B. (2008). Gender diversity in corporate governance and top management. Journal of Business Ethics, 81 (1), 83-95. doi: $10.1007 / \mathrm{s} 10551-007-9482-5$.

[27] Freeman, R. E. (1984). Strategic management: A stakeholder approach. Boston, MA: Pitman.

[28] Garba, T. \& Abubakar, B. A. (2014). Corporate board diversity and financial performance of insurance companies in Nigeria: an application of panel data approach. Asian Economic and Financial Review, 4 (2): 257-277. Retrieved from www.aessweb.com.

[29] Groysberg, B. \& Bell, D. (2013). Dysfunction in the boardroom. Harvard Business Review, Retrieved from www. hbr.org.

[30] Harjoto, M., Laksmana, I., \& Lee, R. (2015). Board diversity and corporate social responsibility. Journal of Business Ethics, 132, 641-660. doi: 10.1007/s10551-0142343.

[31] Hillman, A. J., Cannella, A. A. \&Harris, I. C. (2002). Women and Racial Minorities in the Boardroom: How Do Directors Differ? Journal of Management, 28 (6): 747-763. Doi: $10.1177 / 014920630202800603$.

[32] Hoang, T. C., Abeysekera, I., \& Ma, S. (2016). Board diversity and corporate social disclosure: Evidence from Vietnam. Journal of Business Ethics, 1-20. doi: 10.1007/s10551-016$3260-1$. 
[33] International Finance Corporation (IFC) (2019). Women on boards in Nigeria. Retrieved from www.ifc.org.

[34] Imade, O. G. (2019). Board gender diversity, non-executive director's composition and corporate performance: Evidence from listed firms in Nigeria. African Journal of Business $\begin{array}{llll}\text { Management, } & 13 & (9), \quad 283-290 . & \text { doi: }\end{array}$ 10.5897/AJBM2019.8766.

[35] Jensen, M. C. \& Meckling, W. (1976). Theory of the Firm: Managerial behaviour, Agency Costs, and ownership structure. Journal of Financial Economics, 3 (4), 305-360. Retrieved from www.josephmahoney.web.illinois.edu.

[36] Johnson, J. L: Daily, C. M. \& Ellstrand, A. E. (1996). Boards of Directors: A Review and Research Agenda. Journal of Management, 22 (3), 409-438. doi: $10.1177 / 014920639602200303$.

[37] Jones, T. M., Harrison, J. S., \& Felps, W. (2018). How applying instrumental stakeholder theory can provide sustainable competitive advantage. Academy of Management Review, 43 (3), 371-391. doi: 10.5465/amr.2016.0111.

[38] Kacperczyk, A. (2009). With greater power comes greater responsibility? Takeover protection and corporate attention to stakeholders. Strategic Management Journal, 30, 261-285. doi: 10.1002/smj.733.

[39] Kochan, T. A., \& Rubinstein, S. A. (2000). Toward a stakeholder theory of the firm. Organization Science, 11, 367-386. doi: 10.1287/orsc.11.4.367.14601.

[40] Krishnan, G. V. \& Parsons, L. M. (2008). Getting to the bottom line: An exploration of gender and earnings quality. Journal of Business Ethics, 78 (1-2), 65-76. Retrieved from doi: 10.1007/s10551-006-9314-z.

[41] Kwanbo, M. L, \& Abdul-Qadir, A. B (2013). Board composition, executive duality, and banks' performance in the post-consolidation era in Nigeria. International Journal of Academic Research in Economics and Management Sciences 2 (1), 1-17. Retrieved from www.semanticscholar.org.

[42] Leung, E. Y. W. (2015). Diversifying the board - A step towards better governance. Retrieved from www.accaglobal.com.

[43] Lincoln, A. \& Adedoyin, O. (2012). Corporate governance and gender diversity in Nigerian boardrooms. World Academy of Science, Engineering and Technology, 71, 1853-1859. Retrieved from www.publications.waset.org.

[44] Mainardes, E. W., Alves, H., \& Raposo, M. (2011). Stakeholder theory: Issues to resolve. Management Decision, 49, 226-252. doi: 10.1108/00251741111109133.

[45] McKinsey and Company (2018). Delivering through diversity: Diversity and inclusion. Retrieved from www.mckinsey.com.

[46] McKinsey and Company (2020). Diversity wins: How inclusion matters. Retrieved from www.mckinsey.com.

[47] Michelon, G., \&Parbonetti, A. (2012). The effect of corporate governance on sustainability disclosure. Journal of Management \& Governance, 16 (3), 477-509. doi: 10.1007/s10997-010-9160-3.
[48] Mohammad, S. J., Abdullatif, M. \& Zakzouk, F. (2018). The effect of gender diversity on the financial performance of Jordanian Banks. Academy of Accounting and Financial $\begin{array}{lllll}\text { Studies Journal. } 22 & \text { (2), 1-11. Retrieved }\end{array}$ fromwww.abacademies.org.

[49] Navitidad, I. (2015). Where are the women: Inclusive boardrooms in Africa's top listed companies? Corporate Women Directors International. African Development Bank. 7-117 Retrieved from www.afdb.org.

[50] Nicholson, G. J. \& Kiel, G. C. (2007). Can directors impact performance? A case-based test of three theories of corporate governance. Corporate Governance: An International Review, 15 (4): 585-608. doi: 10.1111/j.14678683.2007.00590.x.

[51] Ogboi, C., Aderimiki, V. O. \& Enilolobo, O. S. (2018). Corporate board diversity and performance of deposit money banks in Nigeria. International Journal of Humanities and Social Science, 8, 112-120. Retrieved from www.ijhssnet.com.

[52] Osae-Brown, A. (2020). Female board positions shows nigeria beats world average. Bloomberg Business. Retrieved from www.bloomberg.com.

[53] Ouedraogo, A. (2018). Determinants of under-representation of women on Boards of Directors: an exploratory study of African public and private firms. Economics and Business Review, 4 (18), 98-113. doi: 10.18559/ebr.2018.2.6.

[54] Panda, B, Leepsa, N. M. (2017). Agency theory: Review of theory and Evidence onproblems and perspectives. Indian Journal of Corporate Governance 10, 74-95. doi: $10.1177 / 0974686217701467$.

[55] Perrow, C. (1986). Complex organizations. New York, NY: Random House.

[56] Peterson Institute for International Economics (2014). Is gender diversity profitable? Evidence from a global survey. Retrieved from www.piie.com.

[57] Pfeffer, J. (1983). Organizational Demography. In B. Staw and L. Cummings (Eds.), Research in Organizational Behavior, 5, 299-357. Retrieved from www. escholarship.org.

[58] Pfeffer, J., G. R. Salancik (1978). A social information processing approach to job attitudes and task design, Administrative Science Quarterly, 23 (2), 224-253. Retrieved from www.pubmed.ncbi.nlm.nih.gov.

[59] Pfeffer, J. (1972). Size, the composition of corporate boards of directors: The organization and its environment. Administrative Science Quarterly, 17 218-228. doi: 10.2307/2393956.

[60] Post, C., Rahman, N., \&Rubow, E. (2011). Green governance: Boards of directors composition andenvironmental corporate social responsibility. Business \& Society, $50 \quad$ (1), 189-223. doi: $10.1177 / 0007650310394642$.

[61] Rao, K., Tilt, C. A., \& Lester, L. H. (2012). Corporate governance and environmental reporting: An Australian study. Corporate governance: The International Journal of Business in Society, 12 (2), 143-163. doi: 10.1108/14720701211214052. 
[62] Robbins, S. \& DeCenzo, D. (2005). Fundamentals of Human Resource management. Pearson Education.

[63] Rose, C. (2007). Does female board representation influence firm performance? The Danish Evidence. Corporate Governance: An International Review 15 (2), 404-413. doi: 10.1111/j.1467-8683.2007.00570.x.

[64] Reguera-Alvardo, N., de Fuentes, P. \& Laffarga, J. (2015). Does board gender diversity influence financial performance? Evidence from Spain. Journal of Business Ethics, 141 (2), 337-350. doi: 10.1007/s10551-015-2735-9.

[65] Rupley, K. H., Brown, D., \& Marshall, R. S. (2012). Governance, media, and the quality of environmental disclosure. Journal of Accounting and Public Policy, 31 (6), 610-640. doi: 10.1016/j.jaccpubpol.2012.09.002.

[66] Şener, I. \& Karaye, A. B. (2014). Board composition and gender diversity: Comparison of Turkish and Nigerian listed companies. 10th International Strategic Management Conference. Procedia - Social and Behavioral Sciences 150, 1002-1011. Retrieved from www.sciencedirect.com.

[67] Smith, A., \& Cannan, E. (2003). The wealth of nations. New York, N. Y: Bantam Classic.

[68] Squires, B. \& Elnahla, N (2020) The roles played by boards of directors: An integration of the agency and stakeholder theories, Transnational Corporations Review, 12 (2), 126139, doi: 10.1080/19186444.2020.1757340.

[69] Swartz, N. P. \& Firer, S. (2005). Board structure and intellectual capital performance in South Africa. Meditari Accountancy Research, 13 (2), 145-166. doi: 10.1108/10222529200500017.

[70] Suleiman, J. M., Modar, A. \& Fida, Z. (2018). The effect of gender diversity on the financial performance of Jordanian banks. Academy of Accounting and Financial Studies Journal, 22 (2), 1-11. Retrieved from www.abacademies.org.
[71] St-Onge, S., \& Magnan, M. (2013). Les femmes au sein des conseils d'administration: bilan des connaissances et voies de recherche future. Revue Finance, Controle etStrategie, 16 (1), 2-25. doi: $10.4000 /$ fcs. 1292.

[72] Temile, S. O, Jatmiko, D. P, \& Hidayat, S (2018). Gender diversity, earnings management practices and corporate performance in Nigerian quoted firms. International Journal of Economics, Commerce, and Management 6 (1), 23-37. ijecm.co.uk.

[73] Ujunwa, A., Nwakoby, I. \& Ugbam, C. O. (2012). Corporate board diversity and firm performance: Evidence from Nigeria. Corporate Ownership \& Control, 9 (2), 216-226. Retrieved from www.virtusinterpress.org.

[74] Wasserman, N. (2006). Stewards, agents, and the founder discount: Executive compensation innew ventures. Academy of Management Journal, 49 (5), 960-976. doi: 10.5465/amj.2006.22798177.

[75] Woetzel, J. et al. (2018). The power of parity: advancing women's equality in Asia pacific. Shanghai: The McKinsey Global Institute Report. Retrieved from www.mckinsey.com.

[76] Woolley, A. W., Chabris, C. F., Pentland, A., Hashmi, N. \& Malone, T. W. (2010). Evidence for a collective intelligence factor in the performance of human groups. Science, 330, 686-688. doi: 10.1126/science.1193147.

[77] Willows, G. \& Van Der Linde, M. (2016). Women representation on boards: A South African perspective. Meditari Accountancy Research, 24 (2), 211-225. Retrieved from www.ideas.repec.org.

[78] Women in Management and Business (WIMBIZ) (2012). Nigerian females on corporate boards. Women in Management and Business (WIMBIZ). Retrieved from www.wimbiz.org. 